\title{
A Comparison of Two Criticality Accident Alarm System Detector Locations for the X-700 Building at the Portsmouth Gaseous Diffusion Plant
}

\section{RECEIVED MAR 271996 OSTI}

February 1996

by

Catherine W. Skapik

Billy L. Lee, Jr.

Battelle

Under LMUS Contract 400183

LOCKHEED MARTIN UTILITY SERVICES, INC.

P.O. Box 628 Piketon, Ohio 45661

Under Contract USECHQ-93-C-0001

to the

\section{U.S. ENRICHMENT CORPORATION}

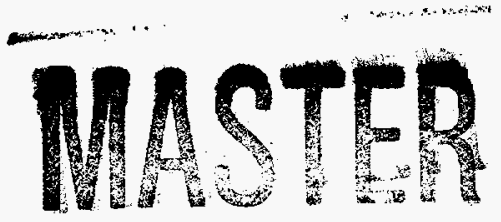




\section{NOTICE}

This report was prepared as an account of work sponsored by an agency of the United States Government. Neither the United States Government nor any agency thereof, nor any of their employees makes any warranty, express or implied, or assumes any legal liability or responsibility for the accuracy, completeness, or usefulness of any information, apparatus, product, or process disclosed, or represents that its use would not infringe privately owned rights. Reference herein to any specific commercial product, process, or service by trade name, trademark, manufacturer, or otherwise does not necessarily constitute or imply its endorsement, recommendation, or favoring by the United States Government or any agency thereof. The views and opinions of authors expressed herein do not necessarily state or reflect those of the United States Government or any agency thereof.

Available to DOE and DOE Contractors from the Office of Scientific and Technical Information, P.O. Box 62, Oak Ridge, TN 37831; prices available from (615) 576-8401, FTS/626-8401.

Available to the public from the National Technical Information Service, U.S. Department of Commerce, 5285 Port Royal Road, Springfield, VA 22161. 


\section{DISCLAMMER}

Portions of this document may be illegible in electronic image products. Images are produced from the best available original document. 


\section{DISTRIBUTION}

\section{Portsmouth}

D'Aquila

R. Dunham

M. Plaster

E. J. Harris

B. Rumble (10)

R. Lemming

J. Smith

Central Files (2)

R. Oxenham

X-710 Technical Library (2)

Technical Review (2)

\section{Battelle-Columbus}

C. Dobelbower

J. Henkel

B. Lee (4)

R. Robinson
C. Skapik

R. Tayloe

J. Woollard 


\section{TABLE OF CONTENTS}

EXECUTIVE SUMMARY

Page

$\begin{array}{lll}1.0 & \text { INTRODUCTION } & 2\end{array}$

$\begin{array}{lll}2.0 & \text { FACILITY DESCRIPTION } & 3\end{array}$

$\begin{array}{lll}3.0 & \text { ANALYSIS } & 6\end{array}$

3.1 Facility Model $\quad 6$

3.2 Source Term $\quad 8$

3.3 Flux Tallies 9

3.4 Variance Reduction $\quad 10$

3.5 Flux to Absorbed Dose Rate Conversion 10

$\begin{array}{llr}\text { 4.0 } & \text { RESULTS } & 14\end{array}$

$\begin{array}{lll}5.0 & \text { DISCUSSION } & 15\end{array}$

$\begin{array}{lll}\text { 6.0 CONCLUSION } & 16\end{array}$

$\begin{array}{lll}7.0 & \text { REFERENCES } & 17\end{array}$

APPENDIX A

SAMPLE MCNP INPUTS FOR THE TWO DETECTOR LOCATIONS 19

APPENDIX B

ABSORBED DOSE RATE CALCULATION SPREADSHEETS 24 


\section{LIST OF TABLES}

Page

1. Material Compositions

2. Criticality Accident Source Locations for Both Models

3. Source Terms for $100 \%$ Enriched ${ }^{235} \mathrm{U}$ Sources

4. Criticality Accident Source Neutron Production Rate

5. Henderson Free-in-Air Tissue Kerma Factors

6. Detector Response for the Original and New X-700 Models

\section{LIST OF FIGURES}

Page

1. Schematic Drawing of the $X-700$ Building Model and the

Locations of the two CAAS Detector Locations and Modeled Sources

2. SABRINA ${ }^{7}$ Plot of the $X-700$ Building Model 


\section{EXECUTIVE SUMMARY}

A previous analysis of the X-700 Building Criticality Accident Alarm System (CAAS) showed that some areas of the building may not adequately be covered by the one building CAAS detector in its current location. ${ }^{1}$ This report compares the results of that analysis with a new analysis where the detector is in a different location.

The new detector location (outside of the storage area in the center of the building - near column B-7) showed coverage for all points previously analyzed. The new centralized detector location reduces the distance and shielding between the source points and the detector. This explains the difference in the level of response when compared to the original (actual) detector location in the new annex west of the building. 


\subsection{INTRODUCTION}

The Portsmouth Gaseous Diffusion Plant (PORTS), located near Piketon, Ohio, is one of two operating gaseous diffusion plants leased from the U.S. Department of Energy (DOE) by the United States Enrichment Corporation (USEC) and managed and operated by Lockheed Martin Utility Services (LMUS). At these plants, uranium (U), in the form of uranium hexafluoride $\left(\mathrm{UF}_{6}\right)$, is enriched through a gaseous diffusion process from its naturally occurring isotopic concentration of $0.7 \%{ }^{235} \mathrm{U}$ up to about $5 \%{ }^{235} \mathrm{U}$ with a plant maximum of $10 \%{ }^{235} \mathrm{U}$. The diffusion cascade process equipment is housed in Buildings X-333, X-330, and X-326. Support services, such as maintenance and decontamination operations, are provided by ancillary facilities at the PORTS site including the X-700 Maintenance Building. ${ }^{2}$

As uranium operations are performed within the process facilities at PORTS, the potential for a criticality accident exists. In the event of a criticality accident within a building at PORTS, a Criticality Accident Alarm System (CAAS) is in place to detect the criticality accident and sound an alarm. According to ANSI standard ANS-8.3-1986 “'American National Standard Criticality Accident Alarm System," the CAAS "shall be designed to detect immediately the minimum accident of concern." In order to meet this requirement, CAAS detectors are located at various positions throughout all of the cascade process buildings and in some of the support services buildings at PORTS.

A previous analysis of the X-700 Building showed that some areas of the plant may not be adequately covered by the one X-700 Building CAAS detector in its current location in the building annex on the west side of the building. This report documents the results of a comparison of the previous analysis with a new analysis where the detector is in a new, more centralized location outside of the offices in the center of the building.

\begin{tabular}{ccc}
\hline $\begin{array}{c}\text { February } \\
1996\end{array}$ & Final Report \\
& A Comparison of Two CAAS Detector \\
Locations for the X-700 Building \\
at the Portsmouth Gaseous Diffusion Plant
\end{tabular}




\subsection{FACILITY DESCRIPTION}

The X-700 Converter Shop and Cleaning Building (the X-700 building) is a permanent structure located about 250 feet north of the X-720 Maintenance Building and 200 feet east of the X-705 Chemical Operations Building. ${ }^{2}$ The X-705 and X-700 buildings are located about 270 feet south of the X-333 Process Building.

The X-700 building has a total floor area of about 104,000 square feet, and is divided into two main sections. The east section is an equipment and parts cleaning area. The west section houses the Converter Shop which is divided into three subsections: north, south, and the west addition. These respective subsections are the Barrier Shop, the Converter/Weld Shop, and the Stabilization Stand. A new addition to the west side of the north barrier shop area, the Radiation Instrument Calibration Facility, was completed in $1986 .^{2}$ The X-700 building contains one CAAS detector. This detector is located in the west subsection of the Converter Shop (the Stabilization Stand). ${ }^{4,5}$ 
POEF-LMUS-02

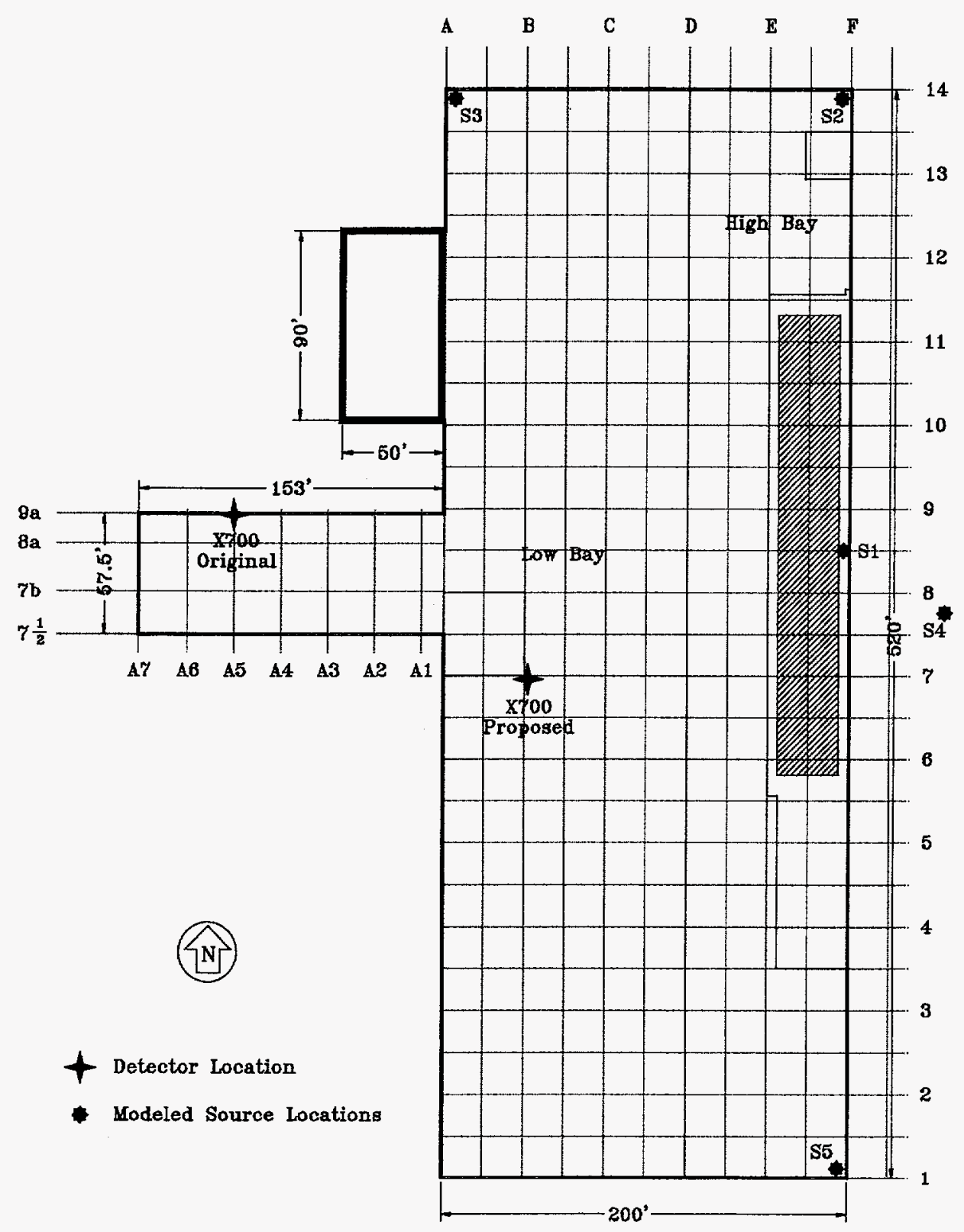

Figure 1 - A Schematic of the X-700 Building Showing the

Source Locations and the Original and Proposed Detector Locations

February 1996
Final Report

A Comparison of Two CAAS Detector

Locations for the X-700 Building

at the Portsmouth Gaseous Diffusion Plant 


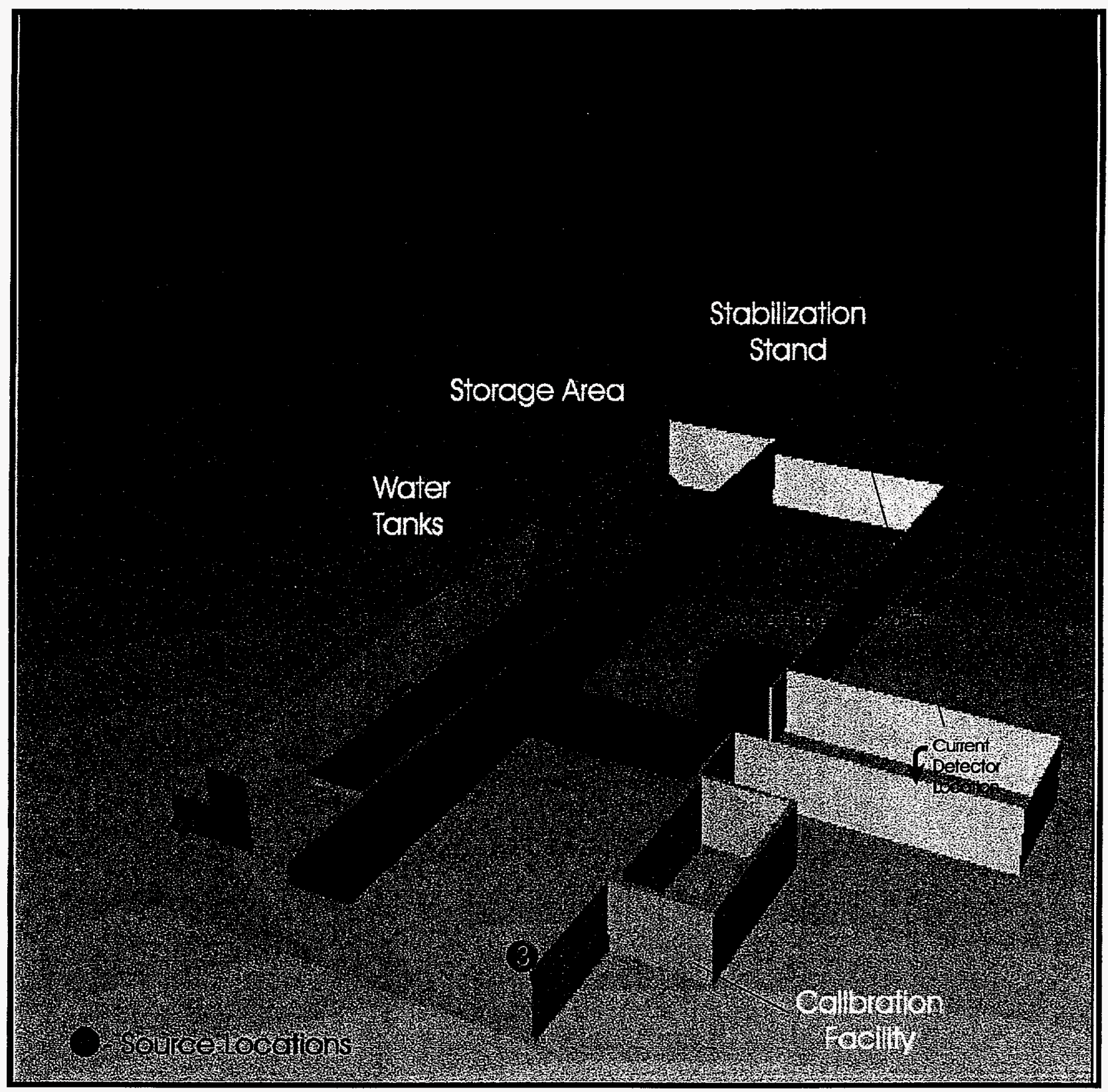

Figure 2 - SABRINA ${ }^{7}$ Plot of the X-700 Building Model

February 1996
Final Report

A Comparison of Two CAAS Detector

Locations for the X-700 Building

at the Portsmouth Gaseous Diffusion Plant 


\subsection{ANALYSIS}

To determine CAAS coverage in the X-700 building, a computer model was developed using the Monte Carlo N-Particle transport code, MCNP4A. ${ }^{6}$ The same model of the X-700 Building was used for both analyses in this report, the only difference being the location of the detector. The location of neutron sources representing minimum criticality accidents were identical in both analyses.

The calculated response of the detectors was used to determine CAAS coverage. If a criticality accident source location resulted in a detector response larger than the PORTS CAAS setpoint of $5 \mathrm{mrad} / \mathrm{hr}$, then a criticality accident at that location would be detected and the CAAS coverage is determined to be adequate. If, however, the detector response was smaller than the PORTS CAAS setpoint, then a criticality accident at that source location may go undetected.

In the original analysis, the calculated detector response for each of the five source locations was below $5 \mathrm{mrad} / \mathrm{hr}$. By moving the detector to a more centralized location outside of the offices in the center of the building, the calculated detector response was raised above 5 $\mathrm{mrad} / \mathrm{hr}$ for the same 5 source locations. Figure 1 shows the locations of source points as well as the original and proposed detector locations.

\subsection{FACILITY MODEL}

The X-700 Building was modeled as a single-story structure approximately 520-feet long by 200 -feet wide (excluding additions). The building model was divided into a high bay over the cleaning area, and a low bay over the rest of the building, the addition, and the calibration building. The outside walls were modeled as full-density homogeneous concrete. The interior walls consist of 8-inch concrete block walls, which were modeled as half-density concrete. The

\begin{tabular}{ccc}
\hline $\begin{array}{c}\text { February } \\
1996\end{array}$ & $\begin{array}{c}\text { Final Report } \\
\text { A Comparison of Two CAAS Detector } \\
\text { Locations for the X-700 Building } \\
\text { at the Portsmouth Gaseous Diffusion Plant }\end{array}$ \\
\hline
\end{tabular}


calibration building wall geometry was simplified and modeled as one room with 3-foot thick concrete walls. The eight tanks located in the high bay cleaning area were simplified into one water-filled tank. A schematic drawing of the building model is shown in Figure 1, while Figure 2 is a SABRINA ${ }^{7}$ plot of the X-700 building model.

\subsubsection{Material Compositions}

For consistency with previous calculations of criticality alarm response in the PORTS buildings, ${ }^{8}$ the number densities of air, concrete, and steel used in this analysis were taken from Westfall et al. ${ }^{9}$ These number densities are given in Table 1.

Table 1 - Material Compositions

\begin{tabular}{|l|l|l|}
\hline Material & Element & $\begin{array}{l}\text { Number Density } \\
\text { (Atom/(barn-cm) })\end{array}$ \\
\hline Air & Nitrogen & $3.570 \mathrm{E}-05$ \\
\cline { 2 - 3 } & Oxygen & $7.840 \mathrm{E}-06$ \\
\hline Concrete & Hydrogen & $1.487 \mathrm{E}-02$ \\
\cline { 2 - 3 } & Carbon & $3.814 \mathrm{E}-03$ \\
\cline { 2 - 3 } & Oxygen & $4.152 \mathrm{E}-02$ \\
\cline { 2 - 3 } & Sodium & $3.040 \mathrm{E}-04$ \\
\cline { 2 - 3 } & Magnesium & $5.870 \mathrm{E}-04$ \\
\cline { 2 - 3 } & Aluminum & $7.350 \mathrm{E}-04$ \\
\cline { 2 - 3 } & Silicon & $6.037 \mathrm{E}-03$ \\
\cline { 2 - 3 } & Calcium & $1.159 \mathrm{E}-02$ \\
\cline { 2 - 3 } & Iron & $1.968 \mathrm{E}-04$ \\
\hline \multirow{5}{*}{ Steel } & Carbon & $3.921 \mathrm{E}-03$ \\
\hline & Iron & \\
\hline
\end{tabular}

February 1996
Final Report

A Comparison of Two CAAS Detector

Locations for the X-700 Building

at the Portsmouth Gaseous Diffusion Plant
Page 7 


\subsection{SOURCE TERM}

To completely model the criticality sources used in the MCNP analysis, the source location, source neutron production rate (power level), and the source neutron energy spectra must be known. The development of each is discussed briefly below.

\subsubsection{Source Locations}

Source locations were chosen that would maximize the distance and/or shielding between the source and the detector. These source locations result in the smallest absorbed dose rates at the detectors. Therefore, any other source location would result in a smaller distance or smaller thickness of shielding between the source and detector and will be bounded by the cases analyzed. The identical five source locations were used for both models. These source locations are listed in Table 2 and shown in Figure 1.

Table 2 - Criticality Accident Source Locations in X-700 Model

\begin{tabular}{||l|l|l|l||}
\hline Source \# & Description & $\begin{array}{l}\text { U-235 } \\
\text { Enrichment (\%) }\end{array}$ & $\begin{array}{l}\text { Power } \\
\text { Level (W) }\end{array}$ \\
\hline S1 & East side of building behind water tank & 100 & 1281 \\
\hline S2 & Northeast corner of building & 100 & 1281 \\
\hline S3 & Northwest corner of building & 100 & 1281 \\
\hline S4 & 50-feet east of building (outside of building) & 100 & 1281 \\
\hline S5 & Southeast corner of building & 100 & 1281 \\
\hline
\end{tabular}




\subsubsection{Source Power Level and Energy Spectrum}

The criticality source used in this analysis was one that results in the minimum critical accident of concern as defined in ANSI/ANS 8.3-1986. ${ }^{3}$

The power level and source neutron energy spectrum for the source used was taken from POEF-SH-31. ${ }^{10}$ The power level for the criticality accident source used in the analysis is shown in Table 2. The source neutron energy spectrum for the criticality accident source modeled is listed in Table 3 . All sources were modeled as isotropic point sources.

\subsection{Flux Tallies}

The CAAS detectors used at the PORTS site are set to alarm at an absorbed dose rate of $5 \mathrm{mrad} / \mathrm{hr} .^{11}$ Values of the neutron flux in air, calculated by MCNP, will be converted to absorbed dose rates through the use of an appropriate flux to absorbed dose rate conversion factor (see section 3.5). Therefore, the detectors modeled in MCNP must tally the neutron flux spectra in air. The MCNP detectors were modeled as spheres with a $1-\mathrm{m}$ diameter at locations corresponding to the currently installed CAAS detectors. ${ }^{3}$ The neutron fluence per source particle at the various detectors was tallied using a next event estimator (point detector) at the center of the detector spheres.

Table 3 - Source Terms for $100 \%$ Enriched ${ }^{235} \mathrm{U}$ Sources

\begin{tabular}{||c|c||}
\hline $\begin{array}{c}\text { Upper Energy } \\
\text { Limit }(\mathrm{MeV})\end{array}$ & $\begin{array}{c}\text { Source Neutron } \\
\text { Energy Spectra }\end{array}$ \\
\hline $2.00 \mathrm{E}+01$ & $1.28 \mathrm{E}+03$ \\
\hline $6.43 \mathrm{E}+00$ & $1.02 \mathrm{E}+04$ \\
\hline $3.00 \mathrm{E}+00$ & $1.13 \mathrm{E}+04$ \\
\hline $1.85 \mathrm{E}+00$ & $5.88 \mathrm{E}+03$ \\
\hline $1.40 \mathrm{E}+00$ & $7.25 \mathrm{E}+03$ \\
\hline $9.00 \mathrm{E}-01$ & $1.03 \mathrm{E}+04$ \\
\hline $4.00 \mathrm{E}-01$ & $8.89 \mathrm{E}+03$ \\
\hline
\end{tabular}

\begin{tabular}{||c|c|}
\hline $\begin{array}{c}\text { Upper Energy Limit } \\
(\mathrm{MeV})\end{array}$ & $\begin{array}{c}\text { Source Neutron } \\
\text { Energy Spectra }\end{array}$ \\
\hline $3.05 \mathrm{E}-06$ & $7.91 \mathrm{E}+02$ \\
\hline $1.77 \mathrm{E}-06$ & $4.79 \mathrm{E}+02$ \\
\hline $1.30 \mathrm{E}-06$ & $1.92 \mathrm{E}+02$ \\
\hline $1.13 \mathrm{E}-06$ & $1.68 \mathrm{E}+02$ \\
\hline $1.00 \mathrm{E}-06$ & $3.17 \mathrm{E}+02$ \\
\hline $8.00 \mathrm{E}-07$ & $9.66 \mathrm{E}+02$ \\
\hline $4.00 \mathrm{E}-07$ & $2.74 \mathrm{E}+02$ \\
\hline
\end{tabular}

Final Report

February

1996 


\begin{tabular}{||c|c||}
\hline $\begin{array}{c}\text { Upper Energy } \\
\text { Limit }(\mathrm{MeV})\end{array}$ & $\begin{array}{c}\text { Source Neutron } \\
\text { Energy Spectra }\end{array}$ \\
\hline $1.00 \mathrm{E}-01$ & $5.83 \mathrm{E}+03$ \\
\hline $1.70 \mathrm{E}-02$ & $3.99 \mathrm{E}+03$ \\
\hline $3.00 \mathrm{E}-03$ & $3.52 \mathrm{E}+03$ \\
\hline $5.50 \mathrm{E}-04$ & $3.21 \mathrm{E}+03$ \\
\hline $1.00 \mathrm{E}-04$ & $2.09 \mathrm{E}+03$ \\
\hline $3.00 \mathrm{E}-05$ & $1.71 \mathrm{E}+03$ \\
\hline $1.00 \mathrm{E}-05$ & $1.79 \mathrm{E}+03$ \\
\hline
\end{tabular}

\begin{tabular}{||c|c||}
\hline $\begin{array}{c}\text { Upper Energy Limit } \\
(\mathrm{MeV})\end{array}$ & $\begin{array}{c}\text { Source Neutron } \\
\text { Energy Spectra }\end{array}$ \\
\hline $3.25 \mathrm{E}-07$ & $4.84 \mathrm{E}+02$ \\
\hline $2.25 \mathrm{E}-07$ & $1.29 \mathrm{E}+03$ \\
\hline $1.00 \mathrm{E}-07$ & $1.28 \mathrm{E}+03$ \\
\hline $5.00 \mathrm{E}-08$ & $7.14 \mathrm{E}+02$ \\
\hline $3.00 \mathrm{E}-08$ & $5.67 \mathrm{E}+02$ \\
\hline $1.00 \mathrm{E}-08$ & $1.04 \mathrm{E}+02$ \\
\hline $1.00 \mathrm{E}-11$ & $0.00 \mathrm{E}+00$ \\
\hline
\end{tabular}

\subsection{VARIANCE REDUCTION}

Because the neutrons tracked in the Monte Carlo simulations have low probabilities of reaching a detector, the large size of the buildings coupled with the number of concrete structures in-between the sources and the detectors could result in calculations that require an enormous amount of computer time. To avoid extremely long computation times, variance-reduction techniques were used. The techniques included the use of point detectors and energy cut off in a particle's random walk.

\subsection{FLUX TO ABSORBED DOSE RATE CONVERSION}

MCNP was used to calculate the neutron fluence per source neutron at the modeled detector locations. In order to calculate the absorbed dose rate in the detectors, the neutron fluence per source neutron was first converted to neutron flux. Then, a flux to neutron absorbed dose rate conversion factor was applied.

To convert the neutron fluence per source particle to neutron flux; the neutron production rate (power level) of the source must be known. The source neutron production rate was determined according to the following equation:

\begin{tabular}{cc}
\hline Final Report \\
$\begin{array}{c}\text { February } \\
1996\end{array}$ & $\begin{array}{c}\text { A Comparison of Two CAAS Detector } \\
\text { Locations for the X-700 Building } \\
\text { at the Portsmouth Gaseous Diffusion Plant }\end{array}$ \\
\hline
\end{tabular}




$$
N\left(\frac{n}{\mathrm{sec}}\right)=\phi_{p}\left(\frac{n}{\mathrm{~cm}^{2} \cdot \mathrm{sec} \cdot W}\right) \times P(W) \times A\left(\mathrm{~cm}^{2}\right)
$$

where

$\mathrm{N}=$ the source neutron production rate

$\phi_{\mathrm{p}}=$ the neutron flux per unit power

$\mathrm{P}=$ power for the minimum critical accident of concern

$\mathrm{A}=$ the surface area of a sphere with radius 2 meters

Using the appropriate values for $\phi_{\mathrm{p}}$ and $\mathrm{P}$ from POEF-SH-31, the neutron source rate for the source term was calculated. The neutron source rate for the criticality accident source modeled is shown in Table 4.

Table 4 - Criticality Accident Source Neutron Production Rate

\begin{tabular}{|l|l|l|}
\hline U-235 Enrichment (\%) & Power Level (W) & Neutron Production Rate (n/s) \\
\hline 100 & 1281 & $5.121 \times 10^{13}$ \\
\hline
\end{tabular}

Next, a conversion factor was applied to the neutron flux to calculate the neutron absorbed dose rate. In this analysis, the neutron absorbed dose rate was calculated on a per energy bin basis. The absorbed dose rate at the detector was calculated using the following equation:

$$
D\left(\frac{m r a d}{h r}\right)=\sum_{i=1}^{27} N\left(\frac{n}{s e c}\right) \times \phi_{i, M C N P}\left(\frac{\left(\frac{\#}{c m^{2}}\right)}{n}\right) \times k_{i}\left(\frac{r a d}{\left(\frac{n}{c^{2}}\right)}\right) \times\left(\frac{3600 \mathrm{sec}}{h r}\right) \times\left(\frac{1000 \mathrm{mrad}}{\mathrm{rad}}\right)
$$

where

$\mathrm{D}$ = neutron absorbed dose rate at detector

$\phi_{\mathrm{MCNP}}=$ the neutron fluence per source particle at detector

February

1996
Final Report

A Comparison of Two CAAS Detector

Locations for the $X-700$ Building

at the Portsmouth Gaseous Diffusion Plant
Page 11 


$$
\begin{aligned}
& \mathrm{N}=\text { source neutron production rate } \\
& \mathrm{k}=\text { neutron flux to neutron absorbed dose rate conversion factor } \\
& \mathrm{i}=\text { energy bin index }
\end{aligned}
$$

In this analysis, the Henderson Free in-Air Tissue kerma factors, ${ }^{13}$ as shown in Table 7, were used. 
Table 5 - Henderson Free-in-Air Tissue Kerma Factors

\begin{tabular}{|c|c|}
\hline $\begin{array}{l}\text { Upper Energy Boundary } \\
\qquad(\mathrm{MeV})\end{array}$ & $\begin{array}{l}\text { Henderson Free in Air Tissue Kerma Factor } \\
\qquad\left(\mathrm{rads} /\left(\mathrm{n} / \mathrm{cm}^{2}\right)\right)\end{array}$ \\
\hline $1.00 \mathrm{E}-11$ & $0.00 \mathrm{E}+00$ \\
\hline $1.00 \mathrm{E}-08$ & $6.03 \mathrm{E}-17$ \\
\hline $3.00 \mathrm{E}-08$ & $2.46 \mathrm{E}-16$ \\
\hline $5.00 \mathrm{E}-08$ & $3.69 \mathrm{E}-16$ \\
\hline $1.00 \mathrm{E}-07$ & $6.52 \mathrm{E}-16$ \\
\hline $2.25 \mathrm{E}-07$ & $1.40 \mathrm{E}-15$ \\
\hline $3.25 \mathrm{E}-07$ & $2.54 \mathrm{E}-15$ \\
\hline $4.00 \mathrm{E}-07$ & $3.37 \mathrm{E}-15$ \\
\hline $8.00 \mathrm{E}-07$ & $5.39 \mathrm{E}-15$ \\
\hline $1.00 \mathrm{E}-06$ & $8.37 \mathrm{E}-15$ \\
\hline $1.13 \mathrm{E}-06$ & $9.93 \mathrm{E}-15$ \\
\hline $1.30 \mathrm{E}-06$ & $1.13 \mathrm{E}-14$ \\
\hline $1.77 \mathrm{E}-06$ & $1.42 \mathrm{E}-14$ \\
\hline $3.05 \mathrm{E}-06$ & $2.20 \mathrm{E}-14$ \\
\hline $1.00 \mathrm{E}-05$ & $5.46 \mathrm{E}-14$ \\
\hline $3.00 \mathrm{E}-05$ & $1.70 \mathrm{E}-13$ \\
\hline $1.00 \mathrm{E}-04$ & $5.43 \mathrm{E}-13$ \\
\hline $5.50 \mathrm{E}-04$ & $2.36 \mathrm{E}-12$ \\
\hline $3.00 \mathrm{E}-03$ & $1.35 \mathrm{E}-11$ \\
\hline $1.70 \mathrm{E}-02$ & $7.20 \mathrm{E}-11$ \\
\hline $1.00 \mathrm{E}-01$ & $3.12 \mathrm{E}-10$ \\
\hline $4.00 \mathrm{E}-01$ & $1.08 \mathrm{E}-09$ \\
\hline $9.00 \mathrm{E}-01$ & $1.79 \mathrm{E}-09$ \\
\hline $1.40 \mathrm{E}+00$ & $2.44 \mathrm{E}-09$ \\
\hline $1.85 \mathrm{E}+00$ & $2.79 \mathrm{E}-09$ \\
\hline $3.00 \mathrm{E}+00$ & $3.22 \mathrm{E}-09$ \\
\hline $6.43 \mathrm{E}+00$ & $4.18 E-09$ \\
\hline $2.00 \mathrm{E}+01$ & $4.72 \mathrm{E}-09$ \\
\hline
\end{tabular}




\subsection{RESULTS}

Detector responses for each source location are presented in Table 6 for both of the detector locations analyzed in the X-700 models.

Table 6 - Detector Response for the Current and Proposed Locations

\begin{tabular}{||c|c|c||}
\hline \multirow{2}{*}{$\begin{array}{c}\text { Source } \\
\text { Location }\end{array}$} & \multicolumn{2}{|c|}{\begin{tabular}{c} 
Detector Response \pm Standard Deviation (mrad/hr) \\
\cline { 2 - 3 }
\end{tabular}} \\
\hline S1(Behind Tanks) & $2.9 \pm 0.20$ & $\begin{array}{c}\text { Proposed Detector } \\
\text { near Column 9a-A5 }\end{array}$ \\
\hline S2 (NE Corner) & $0.5 \pm 0.04$ & $5.47 \pm 0.22$ \\
\hline S3 (NW Corner) & $5.8 \pm 1.26$ & $122.0 \pm 0.77$ \\
\hline S4 (Outside-East) & $3.8 \pm 0.17$ & $16.26 \pm 1.08$ \\
\hline S5 (SE Corner) & $1.3 \pm 0.09$ & $133.2 \pm 1.84$ \\
\hline
\end{tabular}




\subsection{DISCUSSION}

Source locations were chosen which would minimize detector response and which were also credible criticality accident locations. Due to the conservative nature of the selected source locations, all other locations within the range of selected source locations will result in a higher detector response and will, therefore, be bounded by these source locations.

The analysis determines coverage or non-coverage of a location by comparing calculated detector responses to the PORTS CAAS alarm setpoint of $5 \mathrm{mrad} / \mathrm{hr}$. MCNP was run using point detectors to tally the neutron fluence per source particle. The problem was run until the detector tally had a fractional uncertainty of about $5 \%$. At this point the response of this detector was calculated as outlined in section 3.5. If the calculated detector response was greater than or equal to $5 \mathrm{mrad} / \mathrm{hr}$, the area was then considered to be covered by the CAAS.

Using this method, the coverage of the X-700 building by the detector in its current location could not be shown. However, by moving the detector to a more centralized location outside of the storage area in the center of the building (near column B-7), full coverage was shown. This includes the area east of the building, which has not been included in the analyses for the other Portsmouth buildings..

The major contributors to the low detector absorbed dose rates in the original analysis include the distances between the sources used in the evaluation and the detector, and the number of concrete walls that had to be penetrated before a neutron could reach the detector.

\begin{tabular}{ccc}
\hline Final Report \\
$\begin{array}{c}\text { February } \\
1996\end{array}$ & $\begin{array}{c}\text { A Comparison of Two CAAS Detector } \\
\text { Locations for the X-700 Building } \\
\text { at the Portsmouth Gaseous Diffusion Plant }\end{array}$ \\
\hline
\end{tabular}




\subsection{CONCLUSION}

The CAAS detectors at PORTS are set to alarm at an absorbed dose rate of $5 \mathrm{mrad} / \mathrm{hr}$.

Full coverage of the X-700 building can be shown by moving the detector to a location outside of the storage area in the center of the building (near column B-7). Coverage could not be shown for the current detector location as documented in a previous report ${ }^{1}$. 


\subsection{REFERENCES}

1. Skapik, C. W. et al., "Analysis of Criticality Accident Alarm System Coverage in the X-700, X-705, and X-720 Facilities, POEF-SH-39, Lockheed Martin Utility Services, Inc.,

December 1995.

2. Portsmouth Gaseous Diffusion Plant Final Safety Analysis Report, Vol. I, II, III, GAT/GDP1073, Martin Marietta Utility Services, Inc., January 1994.

3. "American National Standard Criticality Accident Alarm System," ANSI/ANS-8.3-1986, American Nuclear Society, 1986.

4. X-Site Radiation Alarm System Plot Plan Cable Routing, DWG DX-220J-2E, Rev. 12, June 1986.

5. Building X-700 First Floor Plan, DWG X-700-3A, July 1981.

6. Briesmeister, J. (Editor), "MCNP - A General Monte Carlo N-Particle Transport Code," Version 4A, LA-12625-M, (Available from the Radiation Shielding Information Center as Code Package CCC-200), November 1993.

7. Van Riper, K. A., "SABRINA User's Guide," LA-UR-93-3696 (Available from the Radiation Shielding Information Center as Code Package PSR-242), October 1993.

8. Negron, S. B. and R. W. Tayloe, Jr., "Analysis of the Proposed Relocation of the Neutron Criticality Clusters in the Process Buildings for the Portsmouth Gaseous Diffusion Plant," POEF-SH-12, Martin Marietta Utility Services, Inc., January 1994.

\begin{tabular}{ccc}
\hline February & Final Report \\
1996 & $\begin{array}{c}\text { A Comparison of Two CAAS Detector } \\
\text { Locations for the X-700 Building } \\
\text { at the Portsmouth Gaseous Diffusion Plant }\end{array}$ \\
\hline
\end{tabular}


9. Westfall, R. M. and J. R. Knight, "Radiation Levels in a Gaseous Diffusion Plant Assuming a Low Enriched Criticality Event Corresponding to the ANSI Standard Minimum Accident of Concern," ORNL/CSD/INF-82-7, January 1983.

10. Lee, B.L., et al, "Calculated In-Air Leakage Spectra and Power Levels for the ANSI Standard Minimum Accident of Concern," POEF-SH-31, Martin Marietta Utility Services, Inc., June 1995.

11. Jones, SA, "Replacement GDP Cluster Placement", Goodyear Atomic Corporation Inernal Correspondence, GAT-521-86-22, February 1986. 
APPENDIX A

SAMPLE MCNP INPUT FOR THE

NEW DETECTOR LOCATION

Final Report

February

1996 


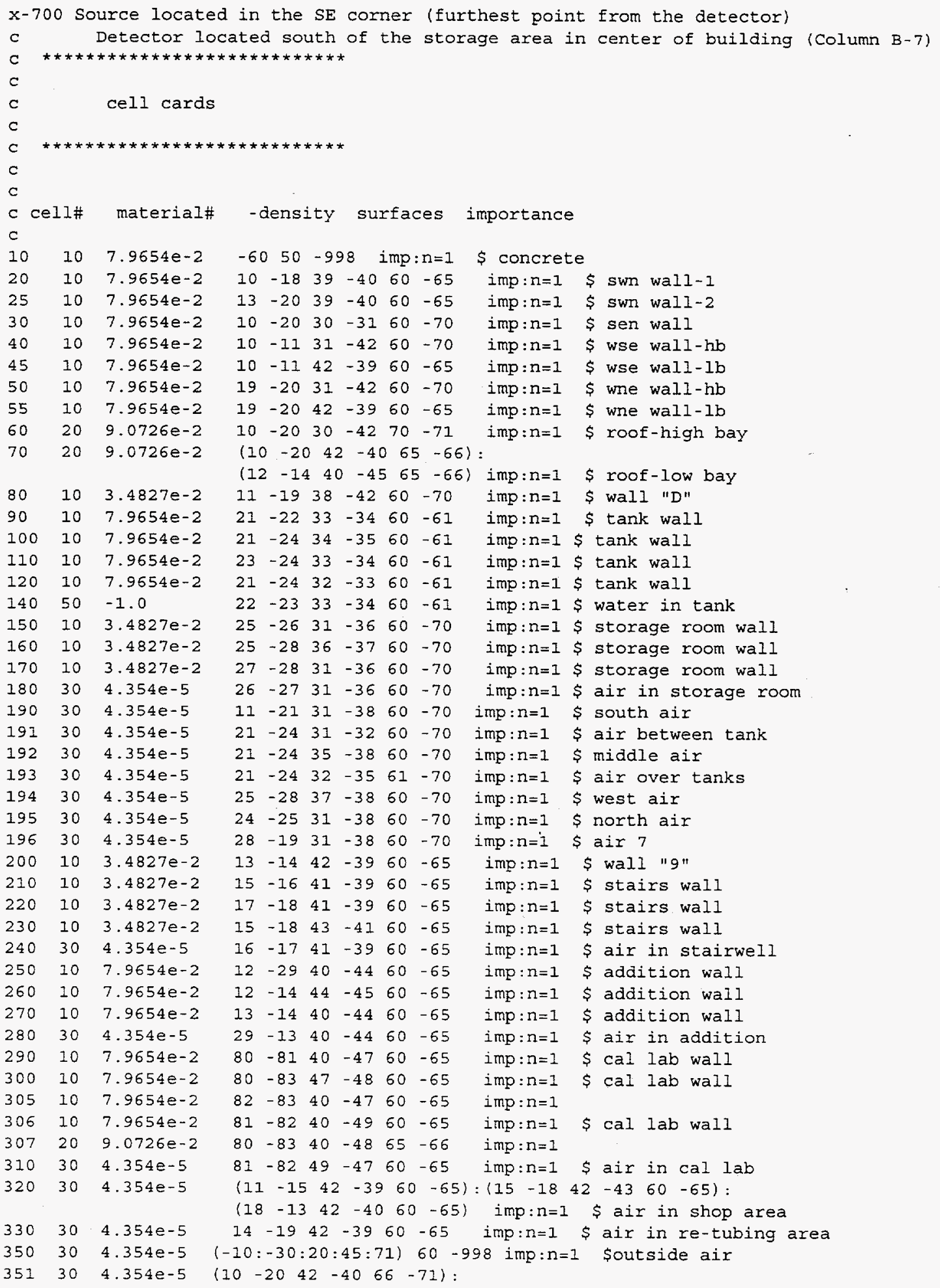

February 1996
Final Report

A Comparison of Two CAAS Detector

Locations for the $X-700$ Building

at the Portsmouth Gaseous Diffusion Plant
Page 20 


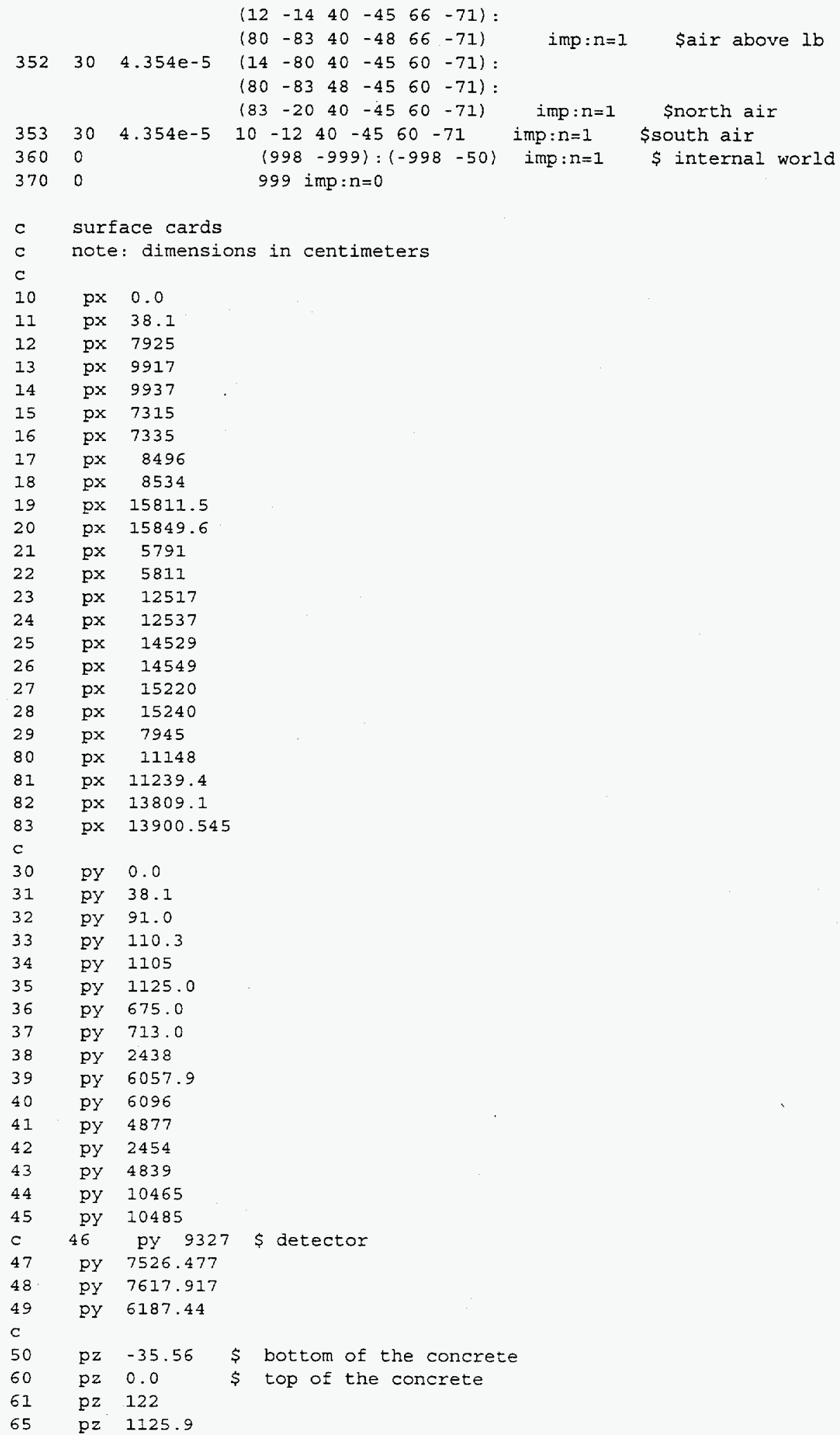


$\$$ internal world

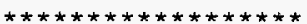

material cards

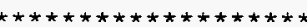

$1001.50 \mathrm{C} \quad 1.487 \mathrm{e}-2$

$6012.50 \mathrm{c} \quad 3.814 \mathrm{e}-3$

$8016.50 \mathrm{c} \quad 4.152 \mathrm{e}-2$

$11023.50 \mathrm{c} \quad 3.040 \mathrm{e}-4$

$12000.51 \mathrm{C} \quad 5.870 \mathrm{e}-4$

$13027.50 \mathrm{c} \quad 7.350 \mathrm{e}-4$

$14000.50 \mathrm{c} \quad 6.037 \mathrm{e}-3$

$20000.51 \mathrm{c} \quad 1.159 \mathrm{e}-2$

$26000.50 \mathrm{c} \quad 1.968 \mathrm{e}-4$

$\mathrm{m} 20$ 1001.50c $4.288 \mathrm{e}-2$

$6012.50 \mathrm{C} \quad 1.812 \mathrm{e}-2$

$8016.50 \mathrm{c} \quad 1.896 \mathrm{e}-3$

$26000.50 c 2.783 e-2$

m30 7014.50c $\quad 3.57 \mathrm{e}-5$

$8016.50 \mathrm{c} \quad 7.840 \mathrm{e}-6$

m50 $1001.50 \mathrm{C} \quad 2.0$

$8016.50 \mathrm{C}$ I. 0

c

C

c peripherals

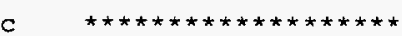

$c$

fc5 Detector!!!!

f5:n $73534788200 \quad 50$

eo $1.00 e-11 \quad 1.00 e-8$

$3.25 e-7 \quad 4.00 e-7$

1. $77 e-6 \quad 3.05 e-6$

0.003

0.017

$3.00 e-8$

$5.00 e-8$

I. $00 e-7$

$2.25 e-7$

$8.00 e-7 \quad 1.00 e-6 \quad 1.13 e-6 \quad 1.3 e-6$

$1.85 \quad 3.0$

$1.00 e^{-5}$

$3.00 e-5$

$5.5 e-4$

. 1

0.4

0.9

1. 4

sdef pos $=500500$ I erg $=\mathrm{d} I$

sc1 from $h / u=120100 \%$ enrichment normalized to $1281 \mathrm{~W}$

$\begin{array}{lllllll}\text { sil h } & 1.00 e-11 & 1.00 e-8 & 3.00 e-8 & 5.00 e-8 & 1.00 e-7 & 2.25 e-7\end{array}$

$\begin{array}{llllll}3.25 e-7 & 4.00 e-7 & 8.00 e-7 & 1.00 e-6 & 1.13 e-6 & 1.3 e-6\end{array}$

$\begin{array}{llllll}1.77 e-6 & 3.05 e-6 & 1.00 e-5 & 3.00 e-5 & 1.00 e-4 & 5.5 e-4\end{array}$

$\begin{array}{llllll}0.003 & 0.017 & 0.1 & 0.4 & 0.9 & 1.4\end{array}$

$\begin{array}{llll}1.85 & 3.0 & 6.43 & 20\end{array}$

$\begin{array}{llllll}\text { spl d } 0 & 1.04 \mathrm{e}+2 & 5.67 \mathrm{e}+2 & 7.14 \mathrm{e}+2 & 1.28 \mathrm{e}+3 & 1.29 \mathrm{e}+3\end{array}$

$4.84 e+2 \quad 2.74 e+2 \quad 9.66 e+2 \quad 3.17 e+2 \quad 1.68 e+2 \quad 1.92 e+2$

$4.79 e+2 \quad 7.91 e+2 \quad 1.79 e+3 \quad 1.71 e+3 \quad 2.09 e+3 \quad 3.21 e+3$

$\begin{array}{llllll}3.52 e+3 & 3.99 e+3 & 5.83 e+3 & 8.89 e+3 & 1.03 e+4 & 7.25 e+3\end{array}$

mode $n$

$5.88 e+3 \quad 1.13 e+4 \quad 1.02 e+4 \quad 1.28 e+3$

cut : n j 0.017

$c$

ctme

7000

February

Final Report

1996

A Comparison of Two CAAS Detector

Locations for the $X-700$ Building

Page 22

at the Portsmouth Gaseous Diffusion Plant 
nps

90000000

prdmp $3 j \quad 4$

print

Final Report

February

1996 


\section{APPENDIX B}

\section{ABSORBED DOSE RATE CALCULATION SPREADSHEETS}


Source \#1

\begin{tabular}{|c|c|c|c|c|c|c|}
\hline \multicolumn{3}{|c|}{ This source is located on the floor between the tanks and the wall. } & & & & \\
\hline & & & & & & \\
\hline & Upper Energy & Henderson Free in Air & & & & \\
\hline & Boundary $(\mathrm{MeV})$ & Tissue Kerma Factor & 9A-A5 Detector & & & \\
\hline & & $\left(\mathrm{rads} /\left(\mathrm{n} / \mathrm{cm}^{\wedge} 2\right)\right)$ & Neutron Fluence/sp & Relative Error & Absorbed Dose & Error \\
\hline & & & & & Rate (rads/s) & \\
\hline & & & & & & \\
\hline Source Rate (n/s) & $1.00 \mathrm{E}-10$ & & & 0 & & \\
\hline $5.47 \mathrm{E}+14$ & $1.00 \mathrm{E}-07$ & $6.03 \mathrm{E}-16$ & & 0 & 0 & 0 \\
\hline $100 \%$ U-235 & $3.00 \mathrm{E}-07$ & $2.46 \mathrm{E}-15$ & & 0 & 0 & 0 \\
\hline$P=1281 \mathrm{~W}$ & $5.00 E-07$ & $3.69 \mathrm{E}-15$ & & 0 & 0 & 0 \\
\hline & $1.00 \mathrm{E}-06$ & $6.52 \mathrm{E}-15$ & & 0 & 0 & 0 \\
\hline & $2.25 \mathrm{E}-06$ & $1.40 \mathrm{E}-14$ & & 0 & 0 & 0 \\
\hline & $3.25 \mathrm{E}-06$ & $2.54 \mathrm{E}-14$ & & 0 & 0 & 0 \\
\hline & $4.00 \mathrm{E}-06$ & $3.37 E-14$ & & 0 & 0 & 0 \\
\hline & $8.00 \mathrm{E}-06$ & $5.39 E-14$ & & 0 & 0 & 0 \\
\hline & $1.00 \mathrm{E}-05$ & $8.37 E-14$ & & 0 & 0 & 0 \\
\hline & $1.13 \mathrm{E}-05$ & $9.93 \mathrm{E}-14$ & & 0 & 0 & 0 \\
\hline & $1.30 \mathrm{E}-05$ & $1.13 \mathrm{E}-13$ & & 0 & 0 & 0 \\
\hline & $1.77 \mathrm{E}-05$ & $1.42 \mathrm{E}-13$ & & 0 & 0 & 0 \\
\hline & $3.05 \mathrm{E}-05$ & $2.20 \mathrm{E}-13$ & & 0 & 0 & 0 \\
\hline & $1.00 \mathrm{E}-04$ & $5.46 \mathrm{E}-13$ & & 0 & 0 & 0 \\
\hline & $3.00 E-04$ & $1.70 \mathrm{E}-12$ & & 0 & 0 & 0 \\
\hline & $1.00 \mathrm{E}-03$ & $5.43 \mathrm{E}-12$ & & 0 & 0 & 0 \\
\hline & $5.50 \mathrm{E}-03$ & $2.46 \mathrm{E}-11$ & & 0 & 0 & 0 \\
\hline & $3.00 \mathrm{E}-02$ & $1.35 \mathrm{E}-10$ & & 0 & 0 & 0 \\
\hline & $1.70 \mathrm{E}-01$ & $7.20 \mathrm{E}-10$ & & 0 & 0 & 0 \\
\hline & $1.00 \mathrm{E}-00$ & $3.12 \mathrm{E}-09$ & $2.06 \mathrm{E}-10$ & 0.0296 & $3.51568 \mathrm{E}-06$ & $1.04064 \mathrm{E}-07$ \\
\hline & $4.00 \mathrm{E}-00$ & $1.08 \mathrm{E}-08$ & $2.23 \mathrm{E}-10$ & 0.0563 & $1.31739 \mathrm{E}-05$ & 7.41693E-07 \\
\hline & $9.00 \mathrm{E}-00$ & $1.79 \mathrm{E}-08$ & $1.84 \mathrm{E}-10$ & 0.0448 & $1.80160 \mathrm{E}-05$ & $8.07116 \mathrm{E}-07$ \\
\hline & $1.40 \mathrm{E}+01$ & $2.44 \mathrm{E}-08$ & $7.27 E-11$ & 0.0711 & $9.70312 \mathrm{E}-06$ & $6.89892 \mathrm{E}-07$ \\
\hline & $1.85 E+01$ & $2.79 \mathrm{E}-08$ & $4.91 \mathrm{E}-11$ & 0.0687 & $7.49330 \mathrm{E}-06$ & $5.14790 \mathrm{E}-07$ \\
\hline & $3.00 E+01$ & $3.22 \mathrm{E}-08$ & $6.66 \mathrm{E}-11$ & 0.0208 & $1.17305 \mathrm{E}-05$ & $2.43995 \mathrm{E}-07$ \\
\hline & $6.43 E+01$ & $4.18 \mathrm{E}-08$ & $2.93 E-11$ & 0.0263 & $6.69933 \mathrm{E}-06$ & $1.76192 \mathrm{E}-07$ \\
\hline & $2.00 E+02$ & $4.72 \mathrm{E}-08$ & $2.58 \mathrm{E}-12$ & 0.1075 & $6.66115 \mathrm{E}-07$ & $7.16073 \mathrm{E}-08$ \\
\hline & & & & & & \\
\hline & & & & & & \\
\hline & & & & Total $A D(\mathrm{rad} / \mathrm{s})=$ & $7.09980 \mathrm{E}-05$ & $1.43145 E-06$ \\
\hline & & & & Total $A D(\mathrm{mrad} / \mathrm{hr})=$ & 25.5592826 & 0.515320789 \\
\hline
\end{tabular}


Source \#2

\begin{tabular}{|c|c|c|c|c|c|c|}
\hline \multicolumn{7}{|c|}{ This source is located in the NE corner of the building. } \\
\hline & & & & & & \\
\hline & Upper Energy & Henderson Free in Air & & & & \\
\hline & Boundary (MeV) & Tissue Kerma Factor & 9A-A5 Detector & & & \\
\hline & & $\left(\mathrm{rads} /\left(\mathrm{n} / \mathrm{cm}^{\wedge} 2\right)\right)$ & Neutron Fluence/sp & Relative Error & Absorbed Dose & Error \\
\hline & & & & & Rate (rads/s) & \\
\hline & & & & & & \\
\hline Source Rate $(\mathrm{n} / \mathrm{s})$ & $1.00 \mathrm{E}-10$ & & & 0 & & \\
\hline $5.47 E+14$ & $1.00 \mathrm{E}-07$ & $6.03 E-16$ & & 0 & 0 & $\overline{0}$ \\
\hline $100 \% \mathrm{U}-235$ & $3.00 \mathrm{E}-07$ & $2.46 \mathrm{E}-15$ & & 0 & 0 & 0 \\
\hline \multirow[t]{29}{*}{$P=1281 \mathrm{~W}$} & 5.00E-07 & $3.69 E-15$ & & 0 & 0 & 0 \\
\hline & $1.00 \mathrm{E}-06$ & $6.52 \mathrm{E}-15$ & & 0 & 0 & 0 \\
\hline & $2.25 \mathrm{E}-06$ & $1.40 \mathrm{E}-14$ & & 0 & 0 & 0 \\
\hline & $3.25 \mathrm{E}-06$ & $2.54 \mathrm{E}-14$ & & 0 & 0 & 0 \\
\hline & $4.00 \mathrm{E}-06$ & $3.37 \mathrm{E}-14$ & & 0 & 0 & 0 \\
\hline & $8.00 \mathrm{E}-06$ & $5.39 \mathrm{E}-14$ & & 0 & 0 & 0 \\
\hline & $1.00 \mathrm{E}-05$ & $8.37 \mathrm{E}-14$ & & 0 & 0 & 0 \\
\hline & $1.13 \mathrm{E}-05$ & $9.93 \mathrm{E}-14$ & & 0 & 0 & 0 \\
\hline & $1.30 \mathrm{E}-05$ & $1.13 \mathrm{E}-13$ & & 0 & 0 & 0 \\
\hline & 1.77E-05 & $1.42 \mathrm{E}-13$ & & 0 & 0 & 0 \\
\hline & $3.05 \mathrm{E}-05$ & $2.20 \mathrm{E}-13$ & & 0 & 0 & 0 \\
\hline & $1.00 \mathrm{E}-04$ & $5.46 \mathrm{E}-13$ & & 0 & 0 & 0 \\
\hline & $3.00 \mathrm{E}-04$ & $1.70 \mathrm{E}-12$ & & 0 & 0 & 0 \\
\hline & $1.00 \mathrm{E}-03$ & $5.43 \mathrm{E}-12$ & & 0 & 0 & 0 \\
\hline & $5.50 E-03$ & $2.46 \mathrm{E}-11$ & & 0 & 0 & 0 \\
\hline & $3.00 \mathrm{E}-02$ & $1.35 \mathrm{E}-10$ & & 0 & 0 & 0 \\
\hline & $1.70 \mathrm{E}-01$ & $7.20 \mathrm{E}-10$ & & 0 & 0 & 0 \\
\hline & $1.00 \mathrm{E}-00$ & $3.12 \mathrm{E}-09$ & $2.21 \mathrm{E}-11$ & 0.0889 & $3.77167 \mathrm{E}-07$ & $3.35302 E-08$ \\
\hline & $4.00 \mathrm{E}-00$ & $1.08 \mathrm{E}-08$ & $2.66 \mathrm{E}-11$ & 0.1151 & $1.57142 \mathrm{E}-06$ & $1.80871 \mathrm{E}-07$ \\
\hline & $9.00 \mathrm{E}-00$ & $1.79 \mathrm{E}-08$ & $2.13 \mathrm{E}-11$ & 0.0831 & $2.08555 \mathrm{E}-06$ & $1.73309 \mathrm{E}-07$ \\
\hline & $1.40 E+01$ & $2.44 \mathrm{E}-08$ & $1.47 \mathrm{E}-11$ & 0.1371 & $1.96198 \mathrm{E}-06$ & $2.68987 E-07$ \\
\hline & $1.85 \mathrm{E}+01$ & $2.79 E-08$ & $1.10 \mathrm{E}-11$ & 0.1421 & $1.67874 \mathrm{E}-06$ & $2.38549 \mathrm{E}-07$ \\
\hline & $3.00 \mathrm{E}+01$ & $3.22 \mathrm{E}-08$ & $2.33 \mathrm{E}-11$ & 0.1047 & $4.10392 E-06$ & $4.29681 E-07$ \\
\hline & $6.43 \mathrm{E}+01$ & $4.18 \mathrm{E}-08$ & $1.24 \mathrm{E}-11$ & 0.0231 & $2.83521 \mathrm{E}-06$ & $6.54934 \mathrm{E}-08$ \\
\hline & $2.00 E+02$ & $4.72 \mathrm{E}-08$ & $2.29 \mathrm{E}-12$ & 0.0427 & $5.91241 \mathrm{E}-07$ & $2.52460 \mathrm{E}-08$ \\
\hline & & & & & & \\
\hline & & & & & & \\
\hline & & & & Total AD $(\mathrm{rad} / \mathrm{s})=$ & $1.52052 \mathrm{E}-05$ & $6.18617 \mathrm{E}-07$ \\
\hline & & & & Total AD $(\mathrm{mrad} / \mathrm{hr})=$ & 5.4738837 & 0.22270203 \\
\hline
\end{tabular}


Source \#3

\begin{tabular}{|c|c|c|c|c|c|c|}
\hline \multicolumn{3}{|c|}{ This source is located in the NW corner of the building. } & & & & \\
\hline & & & & & & \\
\hline & Upper Energy & Henderson Free in Air & & & & \\
\hline & Boundary (MeV) & Tissue Kerma Factor & 9A-A5 Detector & & & \\
\hline & & $\left(\mathrm{rads} /\left(\mathrm{n} / \mathrm{cm}^{\wedge} 2\right)\right)$ & Neutron Fluence/sp & Relative Error & Absorbed Dose & Error \\
\hline & & & & & Rate $(\mathrm{rads} / \mathrm{s})$ & \\
\hline & & & & & & \\
\hline Source Rate (n/s) & $1.00 \mathrm{E}-10$ & & & 0 & & \\
\hline $5.47 \mathrm{E}+14$ & $1.00 \mathrm{E}-07$ & $6.03 \mathrm{E}-16$ & & 0 & 0 & 0 \\
\hline $100 \%$ U-235 & $3.00 \mathrm{E}-07$ & $2.46 \mathrm{E}-15$ & & 0 & 0 & 0 \\
\hline$P=1281 \mathrm{~W}$ & $5.00 \mathrm{E}-07$ & $3.69 \mathrm{E}-15$ & & 0 & 0 & 0 \\
\hline & $1.00 \mathrm{E}-06$ & $6.52 \mathrm{E}-15$ & & 0 & 0 & 0 \\
\hline & $2.25 \mathrm{E}-06$ & $1.40 \mathrm{E}-14$ & & 0 & 0 & 0 \\
\hline & $3.25 \mathrm{E}-06$ & $2.54 \mathrm{E}-14$ & & 0 & 0 & 0 \\
\hline & $4.00 \mathrm{E}-06$ & $3.37 \mathrm{E}-14$ & & 0 & 0 & 0 \\
\hline & $8.00 \mathrm{E}-06$ & $5.39 E-14$ & & 0 & 0 & 0 \\
\hline & $1.00 \mathrm{E}-05$ & $8.37 \mathrm{E}-14$ & & 0 & 0 & 0 \\
\hline & $1.13 \mathrm{E}-05$ & $9.93 \mathrm{E}-14$ & & 0 & 0 & 0 \\
\hline & $1.30 \mathrm{E}-05$ & $1.13 \mathrm{E}-13$ & & 0 & 0 & 0 \\
\hline & $1.77 \mathrm{E}-05$ & $1.42 \mathrm{E}-13$ & & 0 & 0 & 0 \\
\hline & $3.05 \mathrm{E}-05$ & $2.20 \mathrm{E}-13$ & & 0 & 0 & 0 \\
\hline & $1.00 \mathrm{E}-04$ & $5.46 \mathrm{E}-13$ & & 0 & 0 & $\frac{0}{0}$ \\
\hline & $3.00 \mathrm{E}-04$ & $1.70 \mathrm{E}-12$ & & 0 & 0 & 0 \\
\hline & $1.00 \mathrm{E}-03$ & $5.43 \mathrm{E}-12$ & & 0 & 0 & 0 \\
\hline & $5.50 \mathrm{E}-03$ & $2.46 \mathrm{E}-11$ & & 0 & 0 & 0 \\
\hline & $3.00 \mathrm{E}-02$ & $1.35 \mathrm{E}-10$ & & 0 & 0 & 0 \\
\hline & $1.70 \mathrm{E}-01$ & $7.20 \mathrm{E}-10$ & & 0 & 0 & 0 \\
\hline & $1.00 \mathrm{E}-00$ & $3.12 \mathrm{E}-09$ & $3.54 \mathrm{E}-10$ & 0.05 & $6.04151 \mathrm{E}-06$ & $3.02075 \mathrm{E}-07$ \\
\hline & $4.00 E-00$ & $1.08 \mathrm{E}-08$ & $4.13 \mathrm{E}-10$ & 0.03 & $2.43984 \mathrm{E}-05$ & $7.31952 E-07$ \\
\hline & $9.00 \mathrm{E}-00$ & $1.79 \mathrm{E}-08$ & $4.52 \mathrm{E}-10$ & 0.03 & $4.42567 \mathrm{E}-05$ & $1.32770 \mathrm{E}-06$ \\
\hline & $1.40 E+01$ & $2.44 \mathrm{E}-08$ & $2.32 \mathrm{E}-10$ & 0.02 & $3.09646 \mathrm{E}-05$ & $6.19292 \mathrm{E}-07$ \\
\hline & $1.85 \mathrm{E}+01$ & $2.79 \mathrm{E}-08$ & $2.19 \mathrm{E}-10$ & 0.01 & $3.34222 \mathrm{E}-05$ & $3.34222 \mathrm{E}-07$ \\
\hline & $3.00 E+01$ & $3.22 E-08$ & $5.30 E-10$ & 0.01 & $9.33510 \mathrm{E}-05$ & $9.33510 \mathrm{E}-07$ \\
\hline & $6.43 E+01$ & $4.18 \mathrm{E}-08$ & $4.00 \mathrm{E}-10$ & 0.01 & $9.14584 \mathrm{E}-05$ & $9.14584 \mathrm{E}-07$ \\
\hline & $2.00 E+02$ & $4.72 \mathrm{E}-08$ & $5.87 E-11$ & 0.01 & $1.51554 \mathrm{E}-05$ & $1.51554 \mathrm{E}-07$ \\
\hline & & & & & & \\
\hline & & & & & & \\
\hline & & & & Total AD $(\mathrm{rad} / \mathrm{s})=$ & $3.39048 \mathrm{E}-04$ & $2.14846 \mathrm{E}-06$ \\
\hline & & & & Total AD $(\mathrm{mrad} / \mathrm{hr})=$ & 122.0573568 & 0.773446504 \\
\hline
\end{tabular}


Source \#4

\begin{tabular}{|c|c|c|c|c|c|c|}
\hline \multicolumn{7}{|c|}{ This source is located east of the building. } \\
\hline & Upper Energy & Henderson Free in Air & & & & \\
\hline & Boundary (MeV) & Tissue Kerma Factor & 9A-A5 Detector & & & \\
\hline & & $\left(\mathrm{rads} /\left(\mathrm{n} / \mathrm{cm}^{\wedge} 2\right)\right)$ & Neutron Fluence/sp & Relative Error & Absorbed Dose & Error \\
\hline & & & & & Rate (rads/s) & \\
\hline & & & & & & \\
\hline Source Rate $(\mathrm{n} / \mathrm{s})$ & $1.00 \mathrm{E}-10$ & & & 0 & & \\
\hline $5.47 E+14$ & $1.00 \mathrm{E}-07$ & $6.03 \mathrm{E}-16$ & & 0 & 0 & 0 \\
\hline $100 \%$ U-235 & $3.00 E-07$ & $2.46 \mathrm{E}-15$ & & 0 & 0 & 0 \\
\hline \multirow[t]{29}{*}{$P=1281 W$} & $5.00 \mathrm{E}-07$ & $3.69 \mathrm{E}-15$ & & 0 & 0 & 0 \\
\hline & $1.00 E-06$ & $6.52 \mathrm{E}-15$ & & 0 & 0 & 0 \\
\hline & $2.25 \mathrm{E}-06$ & $1.40 E-14$ & & 0 & 0 & 0 \\
\hline & $3.25 \mathrm{E}-06$ & $2.54 \mathrm{E}-14$ & & 0 & 0 & 0 \\
\hline & $4.00 \mathrm{E}-06$ & $3.37 \mathrm{E}-14$ & & 0 & 0 & 0 \\
\hline & $8.00 \mathrm{E}-06$ & $5.39 \mathrm{E}-14$ & & 0 & 0 & 0 \\
\hline & $1.00 \mathrm{E}-05$ & $8.37 \mathrm{E}-14$ & & 0 & 0 & 0 \\
\hline & $1.13 E-05$ & $9.93 \mathrm{E}-14$ & & 0 & 0 & 0 \\
\hline & $1.30 \mathrm{E}-05$ & $1.13 \mathrm{E}-13$ & & 0 & 0 & 0 \\
\hline & $1.77 \mathrm{E}-05$ & $1.42 \mathrm{E}-13$ & & 0 & 0 & 0 \\
\hline & $3.05 E-05$ & $2.20 \mathrm{E}-13$ & & 0 & 0 & 0 \\
\hline & $1.00 \mathrm{E}-04$ & $5.46 \mathrm{E}-13$ & & 0 & 0 & 0 \\
\hline & $3.00 \mathrm{E}-04$ & $1.70 \mathrm{E}-12$ & & 0 & 0 & 0 \\
\hline & $1.00 \mathrm{E}-03$ & $5.43 \mathrm{E}-12$ & & 0 & 0 & 0 \\
\hline & $5.50 E-03$ & $2.46 \mathrm{E}-11$ & & 0 & 0 & 0 \\
\hline & $3.00 \mathrm{E}-02$ & $1.35 \mathrm{E}-10$ & & 0 & 0 & $\mathrm{O}$ \\
\hline & $1.70 \mathrm{E}-01$ & $7.20 \mathrm{E}-10$ & & 0 & 0 & $\mathrm{O}$ \\
\hline & $1.00 \mathrm{E}-00$ & $3.12 \mathrm{E}-09$ & $8.20 \mathrm{E}-11$ & 0.1056 & $1.39944 \mathrm{E}-06$ & $1.47781 \mathrm{E}-07$ \\
\hline & $4.00 \mathrm{E}-00$ & $1.08 \mathrm{E}-08$ & $9.33 \mathrm{E}-11$ & 0.0692 & $5.51179 \mathrm{E}-06$ & $3.81416 \mathrm{E}-07$ \\
\hline & $9.00 \mathrm{E}-00$ & $1.79 \mathrm{E}-08$ & $7.90 \mathrm{E}-11$ & 0.0441 & $7.73513 E-06$ & $3.41119 \mathrm{E}-07$ \\
\hline & $1.40 E+01$ & $2.44 \mathrm{E}-08$ & $5.76 \mathrm{E}-11$ & 0.2641 & $7.68776 \mathrm{E}-06$ & $2.03034 \mathrm{E}-06$ \\
\hline & $1.85 E+01$ & $2.79 \mathrm{E}-08$ & $2.62 \mathrm{E}-11$ & 0.0573 & $3.99846 \mathrm{E}-06$ & $2.29112 \mathrm{E}-07$ \\
\hline & $3.00 E+01$ & $3.22 \mathrm{E}-08$ & $5.88 \mathrm{E}-11$ & 0.2019 & $1.03567 \mathrm{E}-05$ & $2.09101 \mathrm{E}-06$ \\
\hline & $6.43 \mathrm{E}+01$ & $4.18 \mathrm{E}-08$ & $3.19 \mathrm{E}-11$ & 0.0506 & $7.29381 \mathrm{E}-06$ & $3.69067 \mathrm{E}-07$ \\
\hline & $2.00 \mathrm{E}+02$ & $4.72 \mathrm{E}-08$ & $4.61 \mathrm{E}-12$ & 0.0497 & $1.19023 \mathrm{E}-06$ & $5.91543 \mathrm{E}-08$ \\
\hline & & & & & & \\
\hline & & & & & & \\
\hline & & & & Total AD $(\mathrm{rad} / \mathrm{s})=$ & $4.51733 \mathrm{E}-05$ & $2.99508 \mathrm{E}-06$ \\
\hline & & & & Total AD (mrad $/ \mathrm{hr})=$ & 16.26238614 & 1.078227676 \\
\hline
\end{tabular}


Source \#5

\begin{tabular}{|c|c|c|c|c|c|c|}
\hline \multicolumn{7}{|c|}{ This source is located in the southeast corner of the building. } \\
\hline & & & & & & \\
\hline & Upper Energy & Henderson Free in Air & & & & \\
\hline & Boundary (MeV) & Tissue Kerma Factor & 9A-A5 Detector & & & \\
\hline & & $\left(\mathrm{rads} /\left(\mathrm{n} / \mathrm{cm}^{\wedge} 2\right)\right)$ & Neutron Fluence/sp & Relative Error & Absorbed Dose & Error \\
\hline & & & & & Rate (rads/s) & \\
\hline & & & & & & \\
\hline Source Rate $(n / s)$ & $1.00 E-10$ & & & 0 & & \\
\hline $5.47 \mathrm{E}+14$ & $1.00 \mathrm{E}-07$ & $6.03 \mathrm{E}-16$ & & 0 & 0 & 0 \\
\hline $100 \%$ U-235 & $3.00 \mathrm{E}-07$ & $2.46 \mathrm{E}-15$ & & 0 & 0 & 0 \\
\hline \multirow[t]{29}{*}{$\mathrm{P}=1281 \mathrm{~W}$} & $5.00 \mathrm{E}-07$ & $3.69 \mathrm{E}-15$ & & 0 & 0 & 0 \\
\hline & $1.00 \mathrm{E}-06$ & $6.52 \mathrm{E}-15$ & & 0 & 0 & 0 \\
\hline & $2.25 \mathrm{E}-06$ & $1.40 \mathrm{E}-14$ & & 0 & 0 & 0 \\
\hline & $3.25 \mathrm{E}-06$ & $2.54 \mathrm{E}-14$ & & 0 & 0 & 0 \\
\hline & $4.00 E-06$ & $3.37 \mathrm{E}-14$ & & 0 & 0 & 0 \\
\hline & $8.00 \mathrm{E}-06$ & $5.39 \mathrm{E}-14$ & & 0 & 0 & 0 \\
\hline & $1.00 \mathrm{E}-05$ & $8.37 E-14$ & & 0 & 0 & 0 \\
\hline & $1.13 \mathrm{E}-05$ & $9.93 \mathrm{E}-14$ & & 0 & 0 & 0 \\
\hline & 1.30 E-05 & $1.13 \mathrm{E}-13$ & & 0 & 0 & 0 \\
\hline & $1.77 \mathrm{E}-05$ & $1.42 \mathrm{E}-13$ & & 0 & 0 & 0 \\
\hline & $3.05 E-05$ & $2.20 \mathrm{E}-13$ & & 0 & 0 & 0 \\
\hline & $1.00 \mathrm{E}-04$ & $5.46 \mathrm{E}-13$ & & 0 & 0 & 0 \\
\hline & $3.00 \mathrm{E}-04$ & $1.70 \mathrm{E}-12$ & & 0 & 0 & 0 \\
\hline & $1.00 \mathrm{E}-03$ & $5.43 \mathrm{E}-12$ & & 0 & 0 & 0 \\
\hline & $5.50 \mathrm{E}-03$ & $2.46 \mathrm{E}-11$ & & 0 & 0 & 0 \\
\hline & $3.00 \mathrm{E}-02$ & $1.35 \mathrm{E}-10$ & & 0 & 0 & 0 \\
\hline & $1.70 \mathrm{E}-01$ & $7.20 \mathrm{E}-10$ & & 0 & 0 & 0 \\
\hline & $1.00 \mathrm{E}-00$ & $3.12 \mathrm{E}-09$ & $5.31 \mathrm{E}-10$ & 0.0484 & $9.06226 \mathrm{E}-06$ & $4.38613 E-07$ \\
\hline & $4.00 \mathrm{E}-00$ & $1.08 \mathrm{E}-08$ & $5.91 \mathrm{E}-10$ & 0.0371 & $3.49139 \mathrm{E}-05$ & $1.29531 \mathrm{E}-06$ \\
\hline & $9.00 \mathrm{E}-00$ & $1.79 \mathrm{E}-08$ & $5.53 \mathrm{E}-10$ & 0.0298 & $5.41459 \mathrm{E}-05$ & $1.61355 \mathrm{E}-06$ \\
\hline & $1.40 E+01$ & $2.44 \mathrm{E}-08$ & $3.19 \mathrm{E}-10$ & 0.0698 & $4.25763 \mathrm{E}-05$ & $2.97183 \mathrm{E}-06$ \\
\hline & $1.85 \mathrm{E}+01$ & $2.79 \mathrm{E}-08$ & $2.57 \mathrm{E}-10$ & 0.0567 & $3.92215 \mathrm{E}-05$ & $2.22386 \mathrm{E}-06$ \\
\hline & $3.00 \mathrm{E}+01$ & $3.22 \mathrm{E}-08$ & $5.21 \mathrm{E}-10$ & 0.0206 & $9.17658 \mathrm{E}-05$ & $1.89038 \mathrm{E}-06$ \\
\hline & $6.43 E+01$ & $4.18 \mathrm{E}-08$ & $3.71 \mathrm{E}-10$ & 0.0245 & $8.48277 \mathrm{E}-05$ & $2.07828 E-06$ \\
\hline & $2.00 E+02$ & $4.72 E-08$ & $5.21 \mathrm{E}-11$ & 0.0227 & $1.34514 E-05$ & $3.05346 \mathrm{E}-07$ \\
\hline & & & & & & \\
\hline & & & & & & \\
\hline & & & & Total $A D(\mathrm{rad} / \mathrm{s})=$ & $3.69965 \mathrm{E}-04$ & $5.12221 \mathrm{E}-06$ \\
\hline & & & & Total AD $(\mathrm{mrad} / \mathrm{hr})=$ & 133.1873146 & 1.843995609 \\
\hline
\end{tabular}

